\title{
Pharmacological characterization of $\beta_{2}$-adrenoceptor in PGT- $\beta$ mouse pineal gland tumour cells
}

\author{
${ }^{1}$ Byung-Chang Suh, ${ }^{1}$ Hee-Don Chae, ${ }^{2}$ Joo-Ho Chung \& ${ }^{*}, 1$ Kyong-Tai Kim
}

${ }^{1}$ Department of Life Science and Basic Science Research Institute, Pohang University of Science and Technology, Pohang, 790-784, and ${ }^{2}$ Department of Pharmacology, College of Medicine, Kyung Hee University, Seoul, 130-710, Republic of Korea

1 The adrenoceptor in a mouse pineal gland tumour cell line (PGT- $\beta$ ) was identified and characterized using pharmacological and physiological approaches.

2 Adrenaline and noradrenaline, adrenoceptor agonists, stimulated cyclic AMP generation in a concentration-dependent manner, but had no effect on inositol 1,4,5-trisphosphate production. Adrenaline was a more potent activator of cyclic AMP generation than noradrenaline, with half maximal-effective concentrations $\left(\mathrm{EC}_{50}\right)$ seen at $175 \pm 22 \mathrm{nM}$ and $18 \pm 2 \mu \mathrm{M}$ for adrenaline and noradrenaline, respectively.

3 The addition of forskolin synergistically stimulated the adrenaline-mediated cyclic AMP generation in a concentration-dependent manner.

4 The $\mathrm{pA}_{2}$ value for the specific $\beta_{2}$-adrenoceptor antagonist ICI-118,551 (8.7 \pm 0.4$)$ as an antagonist of the adrenaline-stimulated cyclic AMP generation were $\sim 3$ units higher than the value for the $\beta_{\mathrm{I}^{-}}$ adrenoceptor antagonist atenolol $(5.6 \pm 0.3)$.

5 Treatment of the cells with adrenaline and forskolin evoked a $\sim 3$ fold increase in the activity of serotonin $\mathrm{N}$-acetyltransferase with the peak occurring $6 \mathrm{~h}$ after stimulation.

6 These results suggest the presence of $\beta_{2}$-adrenoceptors in mouse pineal cells and a functional relationship between the adenylyl cyclase system and the regulation of $\mathrm{N}$-acetyltransferase expression.

Keywords: Mouse pineal gland cell; $\beta_{2}$-adrenoceptor; adrenaline; noradrenaline; serotonin $\mathrm{N}$-acetyltransferase; adenylyl cyclase

\section{Introduction}

The pineal gland mediates the environmental and circadian regulation of the neuroendocrine system by producing the hormone melatonin (Aronson et al., 1993; Brezezinski, 1997). Melatonin synthesis is controlled by a complex system that includes the circadian oscillator in the suprachiasmatic nucleus (Klein \& Moore, 1979). Rhythmic noradrenergic input occurs from the sympathetic fibres originating in the superior cervical ganglia to the pineal gland activating the pineal adrenoceptors which are coupled to adenylyl cyclase and thus cause an increase of the intracellular level of cyclic AMP (Ebadi \& Govitrapong, 1986; Takahashi, 1993). The cyclic AMPmediated signalling then governs the circadian fluctuation of serotonin $\mathrm{N}$-acetyltransferase gene expression which controls melatonin synthesis (Coon et al., 1995; Roseboom et al., 1996; Baler et al., 1997)

Many recent studies have addressed the regulation of adrenoceptors in pineal gland, as it has become evident that the daily rhythm of melatonin production is linked to the obligate action of $\alpha$-and $\beta$-adrenoceptors. Studies in the rat pineal have described that nocturnally released noradrenaline stimulates melatonin synthesis by acting through $\beta_{1^{-}}$ adrenoceptors linked to the generation of cyclic AMP (Brownstein, 1973; Machida et al., 1990). In addition, $\alpha_{1}$ adrenoceptors which triggers the phosphoinositide pathway and increases intracellular $\mathrm{Ca}^{2+}$ are also present and known to be involved in the potentiation of the stimulatory effects of

* Author for correspondence at: Department of Life Science, POSTECH, San 31, Hyoja dong, Pohang, 790-784, Republic of Korea. the $\beta$-adrenoceptors (Sugden et al., 1985; Yu et al., 1993). However, the small size of pure pinealocytes in primary culture makes difficulties in studying mouse pineal gland. Previously, therefore, a clonal neuroendocrine pineal cell line (PGT- $\beta$ ) was developed from pineal tumour which was established by targeted expression of the tissue-specific regulatory region of tryptophan hydroxylase gene fused to the SV40 early region encoding the large T-antigen in transgenic mice (Son et al., 1996). Several lines of evidence demonstrated that PGT- $\beta$ cells are immortalized pinealocytes. They express functionally active forms of two characteristic marker enzymes of the pinealocyte, tryptophan hydroxylase and $\mathrm{N}$-acetyltransferase, and the activity of the enzymes was enhanced by pharmacological stimulation of the cells with the cyclic AMP analogue dibutyryl cyclic AMP or the $\beta$ adrenergic receptor agonist isoprenaline. Here, utilizing the pineal tumour cell line, we characterized the adrenergic regulation of mouse pineal function. The present study demonstrates the existence of $\beta_{2}$-adrenoceptors on the cells and the evidence indicating that the $\beta_{2}$-adrenoceptormediated signalling is involved in the pineal regulation of expression of $\mathrm{N}$-acetyltransferase.

\section{Methods}

\section{Cell culture method}

The cells were cultured in Dulbecco's modified Eagle's medium (DMEM) (GIBCO, Gaithersburg, MD, U.S.A.) supplemented 
with $10 \%(\mathrm{v} / \mathrm{v})$ heat-inactivated bovine calf serum (Hyclone, Logan, UT, U.S.A.) and $1 \%(\mathrm{v} / \mathrm{v})$ antibiotics containing 5,000 units $\mathrm{ml}^{-1}$ penicillin $\mathrm{G}$ (sodium) and $5,000 \mu \mathrm{g} \mathrm{ml}^{-1}$ streptomycin sulphate in $0.85 \%$ saline buffer (GIBCO), $\mathrm{pH}$ 7.4. Cell cultures were maintained in a humidified atmosphere of $5 \%$ $\mathrm{CO}_{2}$ at $37^{\circ} \mathrm{C}$. Cells grown to confluence were removed from the dishes after a 5 min incubation with $0.25 \%(\mathrm{w} / \mathrm{v})$ trypsin containing $1 \mathrm{mM}$ EDTA (GIBCO). They were subcultured about twice a week.

\section{Cyclic AMP accumulation in whole cells}

Intracellular cyclic AMP was determined by measuring the formation of cyclic $\left[{ }^{3} \mathrm{H}\right] \mathrm{AMP}$ from $\left[{ }^{3} \mathrm{H}\right]$ adenine nucleotide pools as we previously described (Suh \& Kim, 1995). The cells were grown in 6-well dishes to confluency and loaded with $\left[{ }^{3} \mathrm{H}\right]$ adenine $\left(2 \mu \mathrm{Ci} \mathrm{ml}^{-1}\right)$ in complete medium for $24 \mathrm{~h}$. After the loading, the cells were washed three times with Locke's solution $\left(\mathrm{NaCl}, 154 \mathrm{mM} ; \mathrm{KCl}, 5.6 \mathrm{mM} ; \mathrm{MgCl}_{2}, 1.2 \mathrm{mM} ; \mathrm{CaCl}_{2}\right.$, $2.2 \mathrm{mM}$; HEPES, $5.0 \mathrm{~mm}$; glucose, $10 \mathrm{~mm}, \mathrm{pH} 7.4)$ and preincubated with $1 \mathrm{mM}$ isobutylmethylxanthine (IBMX) for 15 min in Locke's solution to inhibit phosphodiesterase. IBMX was also added to the stimulating solution. The reaction was stopped by aspirating the medium off and adding $1 \mathrm{ml}$ of ice-cold $5 \%(\mathrm{w} / \mathrm{v})$ trichloroacetic acid containing $1 \mu \mathrm{M}$ unlabelled cyclic AMP. The plates were left on ice for $30 \mathrm{~min}$ to extract the water-soluble cyclic AMP. Then, the extracts were transferred to Eppendorf tubes and centrifuged at $5000 \times g$ for $5 \mathrm{~min}$ to remove cell debris. $\left[{ }^{3} \mathrm{H}\right]$ cyclic AMP and $\left[{ }^{3} \mathrm{H}\right] \mathrm{ATP}$ were separated by sequential chromatography on Dowex AG50W-X4 (200-400 mesh) cation exchanger and neutral alumina columns. The $\left[{ }^{3} \mathrm{H}\right] \mathrm{ATP}$ fraction was obtained by elution with $2 \mathrm{ml}$ distilled water from the Dowex column, and the sequential elution with $3.5 \mathrm{ml}$ distilled water was loaded onto an alumina column. The alumina column was washed with $4 \mathrm{ml}$ imidazole solution $(0.1 \mathrm{M}, \mathrm{pH} 7.2)$, and eluant fractions were collected into scintillation vials containing $15 \mathrm{ml}$ scintillation fluid prior to counting radioactive decay of the cyclic $\left[{ }^{3} \mathrm{H}\right] \mathrm{AMP}$. The increase in intracellular cyclic AMP concentration was calculated as $\left[{ }^{3} \mathrm{H}\right]$ cyclic AMP $\left(\left[{ }^{3} \mathrm{H}\right] \mathrm{ATP}+\left[{ }^{3} \mathrm{H}\right] \text { cyclic AMP }\right)^{-1} \times 10^{3}$.

\section{Quantification of inositol 1,4,5-trisphosphate in whole cells}

The inositol 1,4,5-trisphosphate concentration in the cells was determined by $\left[{ }^{3} \mathrm{H}\right]$-inositol 1,4,5-trisphophate competition assay in binding to inositiol 1,4,5-trisphosphate binding protein (Suh et al., 1997). To determine the inositol 1,4,5trisphosphate production induced by catecholamine or $\alpha_{1}$ selective agonist, the pineal tumour cells were grown in 6well culture plates to $95 \%$ confluency. The cells were stimulated with agonist for specific intervals, and the reaction was terminated by aspirating the medium off the cells followed by addition of $0.3 \mathrm{ml}$ of ice-cold $15 \%(\mathrm{w} / \mathrm{v})$ trichloroacetic acid containing $10 \mathrm{~mm}$ EGTA. The plates were left on ice for $30 \mathrm{~min}$ to extract the water-soluble inositol phosphate. The extract was then transferred to an Eppendorf tube, and the trichloroacetic acid was removed with four extractions with diethyl ether. Finally the extract was neutralized with $200 \mathrm{~mm}$ Trizma base, and its $\mathrm{pH}$ was adjusted to 7.4. Twenty microlitres of the cell extract was added to $20 \mu \mathrm{l}$ of the assay buffer $(0.1 \mathrm{M}$ tris(hydroxymethyl)aminomethane buffer containing $4 \mathrm{~mm}$ EDTA and $4 \mathrm{mg} \mathrm{ml}^{-1}$ bovine serum albumin) and $20 \mu \mathrm{l}$ of $\left[{ }^{3} \mathrm{H}\right]$ inositol 1,4,5-trisphosphate $\left(0.1 \mu \mathrm{Ci} \mathrm{ml}^{-1}\right)$. Then $20 \mu \mathrm{l}$ of a solution containing the binding protein was added, and the mixture was incubated for $15 \mathrm{~min}$ on ice and centrifuged at $2000 \times g$ for $5 \mathrm{~min}$. The pellet was resuspended in $100 \mu \mathrm{l}$ of water, and $1 \mathrm{ml}$ of scintillation cocktail were added to the pellet to measure radioactivity. The inositol 1,4,5-trisphosphate concentration in the sample was determined based on a standard curve and expressed as picomols per milligram protein in cell extract with trichloroacetic acid. The inositol 1,4,5-trisphosphate binding protein was prepared from bovine adrenal cortex according to the method of Challiss et al. (1990).

\section{$N$-acetyltransferase activity assay}

PGT- $\beta$ cells were grown in $60 \mathrm{~mm}$ culture dishes to $\sim 90 \%$ confluence and stimulated with adrenaline and forskolin for various periods of time. Then the cells were rapidly detached and transferred to an Eppendorf tube and pelleted. The cells in the pellet were disrupted with ultrasound in $80 \mu$ lice-cold phosphate buffer (50 mM, pH 6.8). Debris was removed by centrifugation $\left(15,000 \times g, 5 \mathrm{~min}, 4^{\circ} \mathrm{C}\right)$, and the supernatants were transferred to a new tube. The extract of the PGT- $\beta$ cells was then incubated in the presence of $5 \mu$ l tryptamine$\mathrm{HCl}(10 \mathrm{mM}), 1 \mu \mathrm{l}$ acetyl CoA $(0.5 \mathrm{~mm})$, and $1 \mu \mathrm{l}\left[{ }^{3} \mathrm{H}\right]$ acetyl $\mathrm{CoA}\left(3.6 \mathrm{Ci} \mathrm{mmol}^{-1}, \quad 250 \mu \mathrm{Ci} \mathrm{ml}^{-1}\right.$ ). $50 \mathrm{~mm}$ phosphate buffer ( $\mathrm{pH}$ 6.8) was then added to make a final volume of $20 \mu \mathrm{l}$. Incubation at $37^{\circ} \mathrm{C}$ for $40 \mathrm{~min}$ was stopped by diluting the reaction mixture with an additional $180 \mu \mathrm{l}$ of $50 \mathrm{~mm}$ phosphate buffer ( $\mathrm{pH}$ 6.8). The whole reaction mixture was transferred into a vial containing $3 \mathrm{ml}$ of Econofluor, a water-immiscible scintillation fluid. After an incubation of $15 \mathrm{~min}$ without mixing the amount of radiolabelled acetyltryptamine was determined in a liquid scintillation counter.

\section{Materials}

$( \pm)$-adrenaline, $( \pm)$-noradrenaline, ionomycin, alumina, imidazole, dowex AG50W-X4 (200-400 mesh), trichloroacetic acid, Triton X-100, glucose, HEPES, cyclic AMP, forskolin, acetyl CoA, and tryptamine were obtained from Sigma Chemical Co. (St. Louis, MO, U.S.A.). Isobutylmethylxanthine (IBMX), ( \pm )-atenolol, ICI-118,551 (erythro- $( \pm)$ 1- (7-methyllindane-4- yloxy) -3-isopropylaminobutane-2-olhydrochloride), BRL 37344 (4-[2-[[2-(3-chlorophenyl)-2-hydroxyethyl] amino] propyl] phenoxy) - acetic acid), prazosine, yohimbine, phenylephrine, clonidine, and $( \pm)$-propranolol were purchased from Research Biochemicals Inc. (Natick, MA, U.S.A.). $\left[{ }^{3} \mathrm{H}\right]$ Acetyl CoA was obtained from Amersham (Arlington Heights, IL, U.S.A.) and $\left[{ }^{3} \mathrm{H}\right]$ adenine from DuPont NEN Research Products (Boston, MA, U.S.A.).

\section{Analysis of data}

All quantitative data are expressed as means \pm s.e.mean. Comparison between two groups was analysed using Student's unpaired $t$-test, and comparison among more than two groups was carried out using one-way analysis of variance (ANOVA). Differences were considered to be significant when the degree of confidence in the significance was $95 \%$ or better $(P<0.05)$. Antagonist potencies were evaluated by calculating their $\mathrm{pA}_{2}$ values. Concentration-response curves for agonist were made in the presence of 3-4 different concentrations of antagonists. Allfit program was used to obtain the $\mathrm{EC}_{50}$ from the individual experiments (De Lean et al., 1978) and the $\mathrm{pA}_{2}$ values $\left(-\log \mathrm{mol}^{-1}\right)$ were calculated. 


\section{Results}

Effect of adrenaline and noradrenaline on cyclic AMP generation

The coupling between adrenoceptors and adenylyl cyclase was investigated in a mouse PGT- $\beta$ cell line. Stimulation of the PGT- $\beta$ cells with adrenaline and noradrenaline evoked cyclic AMP generation. The maximal and half maximal responses were obtained by treatments with $1.2 \pm 0.5 \mu \mathrm{M}$ and $175 \pm 22 \mathrm{nM}$ adrenaline, respectively, and $300 \pm 46 \mu \mathrm{M}$ and $18 \pm 2 \mu \mathrm{M}$ noradrenaline, respectively (Figure 1A). Figure 1B shows the time course of cyclic AMP generation induced by $1 \mu \mathrm{M}$ adrenaline and $300 \mu \mathrm{M}$ noradrenaline, the maximal effective concentrations used for each agonist. The peak level of cyclic AMP was obtained 3 min after stimulation with either

\section{A}

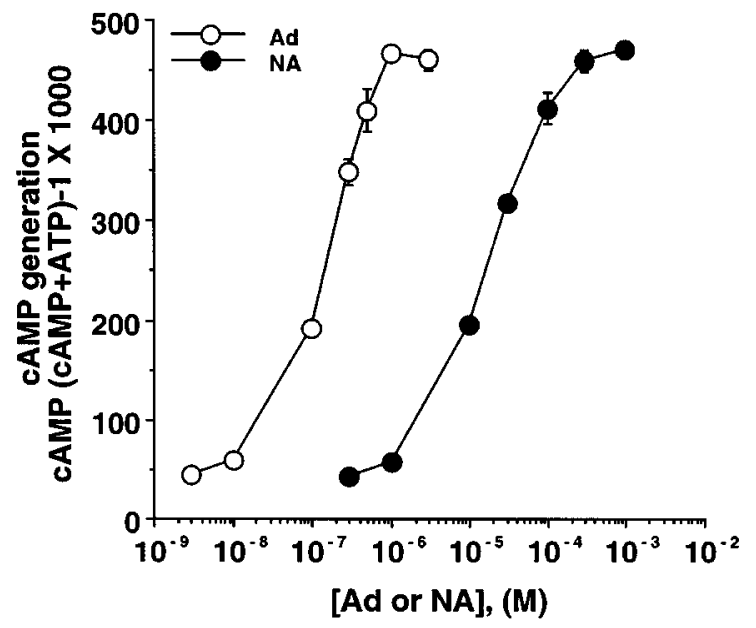

B

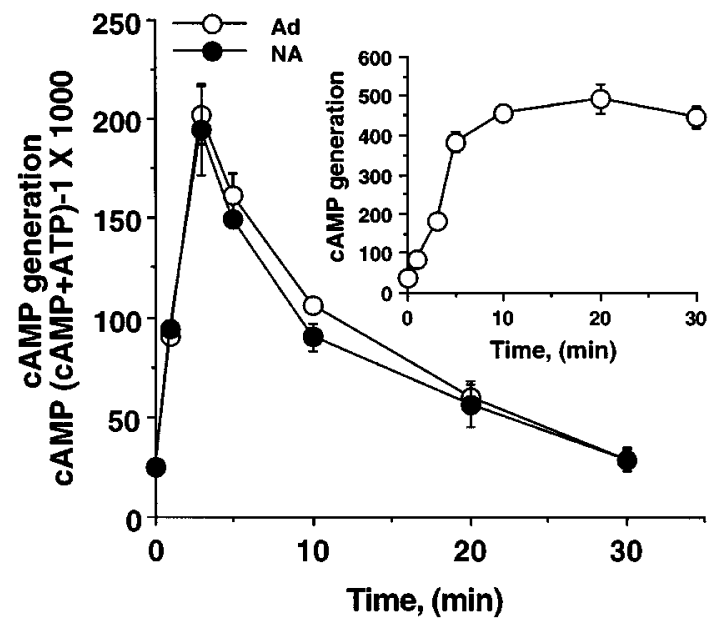

Figure 1 Adrenaline- and noradrenaline-induced cyclic AMP production in PGT- $\beta$ cells. (A) $\left[{ }^{3} \mathrm{H}\right]$ adenine-loaded cells were preincubated with IBMX $(1 \mathrm{mM})$ for $20 \mathrm{~min}$ and then stimulated with variable concentrations of adrenaline (Ad) and noradrenaline (NA) for $20 \mathrm{~min}$. (B) The cells were stimulated with $1 \mu \mathrm{M}$ adrenaline (Ad) or $300 \mu \mathrm{M}$ noradrenaline (NA) for the indicated times $(0,1,3,5$, $10,20,30 \mathrm{~min})$ and cyclic AMP generation was measured as described in Methods. The inset shows the time-dependent changes in cyclic AMP accumulation induced by $1 \mu \mathrm{M}$ adrenaline in the presence of $1 \mathrm{mM}$ IBMX. The experiments were done three times and each point is the mean \pm s.e.mean. agonists and was followed by a rapid decline to the basal level within $30 \mathrm{~min}$. The accumulation of cyclic AMP induced by adrenaline was clearly detectable within $1 \mathrm{~min}$ and was saturated after $20 \mathrm{~min}$ in the presence of the phosphodiesterase inhibitor IBMX (Figure 1B, inset). The results thus indicate that $\beta$-adrenoceptor-mediated cyclic AMP generation is present on the cells.

To investigate whether $\alpha$-adrenoceptors are also expressed in the cells, we treated the cells with subtype selective agonists. Figure $2 \mathrm{~A}$ shows that treatment with adrenaline and the specific $\alpha_{1}$-adrenoceptor agonist phenylephrine had no stimulatory effect on inositol 1,4,5-trisphosphate generation, whereas extracellular ATP significantly increased the inositol 1,4,5-trisphosphate levels through $\mathrm{P}_{2}$ purinoceptor as previously described (Suh et al., 1997). Figure 2B shows that treatment with the $\alpha_{2}$-adrenoceptor agonist clonidine and the $\alpha_{2}$-adrenoceptor antagonist yohimbine did not affect the adrenaline-induced cyclic AMP accumulation, while a general $\beta$-adrenoceptor antagonist propranolol completely inhibited
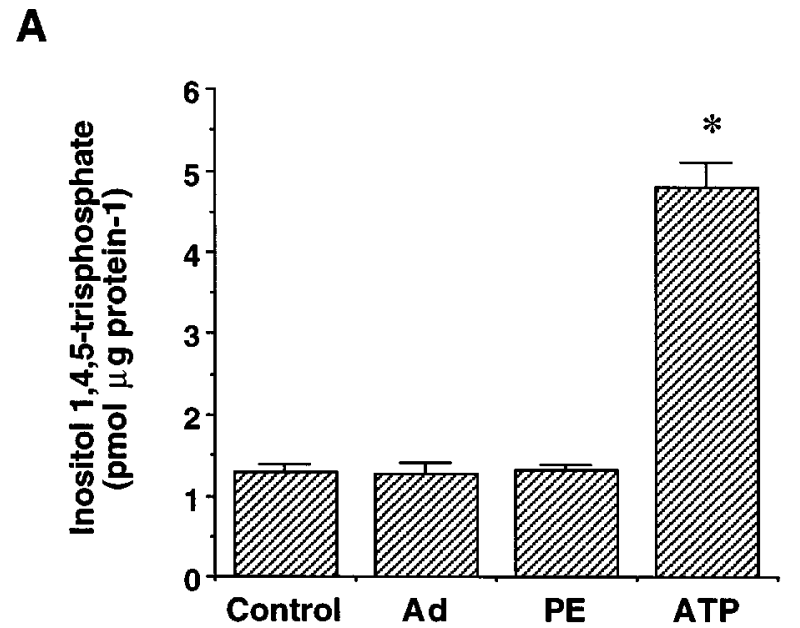

B

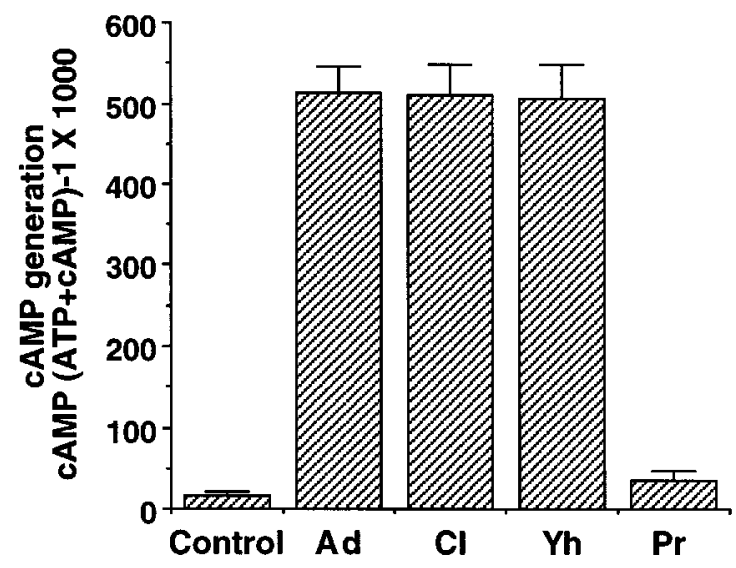

Figure 2 Effect of $\alpha$-adrenoceptor agonist and antagonist in PGT- $\beta$ cells. (A) Cells were stimulated with $1 \mu \mathrm{M}$ adrenaline, $10 \mu \mathrm{M}$ phenylephrine, or $300 \mu \mathrm{M} \mathrm{ATP} \mathrm{for} 30 \mathrm{~s}$, and the reactions were stopped by addition of $15 \%(\mathrm{w} / \mathrm{v})$ trichloroacetic acid containing $10 \mathrm{~mm}$ EGTA. The inositol 1,4,5-trisphosphate generation was measured as described in Methods. (B) $\left[{ }^{3} \mathrm{H}\right]$ adenine-loaded cells were preincubated with IBMX (1 mM) for $20 \mathrm{~min}$ and then stimulated with $1 \mu \mathrm{M}$ adrenaline (Ad) in the absence or presence of $10 \mu \mathrm{M}$ clonidine (Cl), $30 \mu \mathrm{M}$ yohimbine ( $\mathrm{Yh}$ ), and $1 \mu \mathrm{M}$ propranolol (Pr) for $20 \mathrm{~min}$. The cyclic AMP generation was measured as described in Methods. The experiments were done three times and each point is the mean \pm s.e.mean. ${ }^{*} P<0.05$, compared to control. 
the adrenaline-induced cyclic AMP generation. The results, therefore, indicate that $\alpha_{1}$-adrenoceptor which is coupled to phospholipase $\mathrm{C}$ and $\alpha_{2}$-adrenoceptor which is negatively linked to adenylyl cyclase are not expressed in the PGT- $\beta$ cells.

\section{Synergistic activation of adenylyl cyclase by forskolin}

To determine the susceptibility of the adenylyl cyclase coupled to the $\beta$-adrenoceptor to other activating signalling, the effect of a co-treatment with adrenaline and forskolin was examined. Forskolin by itself induced a concentration-dependent cyclic AMP accumulation (Figure 3A, inset), but addition of $1 \mu \mathrm{M}$ adrenaline to each concentration of forskolin synergistically enhanced the forskolin-activated cyclic AMP generation. Cotreatment with $10 \mu \mathrm{M}$ forskolin plus $1 \mu \mathrm{M}$ adrenaline produced a $\sim 20$ fold increase over the $10 \mu \mathrm{M}$ forskolin-generated cyclic AMP level (Figure 3A). Time course of cyclic AMP generation demonstrates that the peak cyclic AMP level was obtained 3 min after stimulation with $10 \mu \mathrm{M}$ forskolin as shown in that of adrenaline or noradrenaline (Figure 3B, inset). However, co-treatment with forskolin and adrenaline resulted in synergistic enhancement of the response with the peak level of cyclic AMP seen at 20 min after stimulation (Figure 3B). The high level of cyclic AMP induced by simultaneous treatment was persistent up to $1 \mathrm{~h}$ even in the absence of IBMX (data not shown). The results thus indicate that the adenylyl cyclase after being maximally stimulated via $\beta$ adrenoceptors could be further stimulated by other $G_{s}$ protein-mediated signalling.

Cytosolic $\mathrm{Ca}^{2+}$-mediated inhibition of adrenaline- and forskolin-stimulated adenylyl cyclase activity

To examine the regulatory role of intracellular $\mathrm{Ca}^{2+}$ on adenylyl cyclase, the cells were treated with ionomycin, a $\mathrm{Ca}^{2+}$ ionophore. Figure 4A shows the time course of cyclic AMP generation induced by adrenaline treatment in the presence or absence of $1 \mu \mathrm{M}$ ionomycin. Addition of ionomycin significantly decreased the adrenaline-induced cyclic AMP generation. The inhibition by ionomycin was concentrationdependent and significant in micromolar concentrations (Figure 4B). Forskolin-stimulated cyclic AMP generation was also inhibited by $\sim 30 \%$ in the presence of $1 \mu \mathrm{M}$ ionomycin (Figure 4C), indicating that intracellular $\mathrm{Ca}^{2+}$ has a direct effect on the adenylyl cyclase rather than the adrenoceptor or other components of the receptor-mediated signalling pathways.

\section{Pharmacological characterization with $\beta$-adrenoceptor antagonists and agonists}

To investigate which subtype of $\beta$-adrenoceptor mediates the effect of adrenaline on cyclic AMP generation, we determined the $\mathrm{pA}_{2}$ values for specific $\beta_{1}$ - and $\beta_{2}$-adrenoceptor blockers in adrenaline concentration-response experiments performed at several concentrations of antagonist in each individual experiment. Figure 5A and $\mathrm{B}$ show that the $\mathrm{pA}_{2}$ value of the selective $\beta_{2}$-adrenoceptor antagonist ICI 118,551 versus adrenaline was $8.7 \pm 0.4$. In a corresponding way the $\mathrm{pA}_{2}$ value for the selective $\beta_{1}$-adrenoceptor antagonist atenolol versus adrenaline was $5.6 \pm 0.3$ (Figure $5 \mathrm{C}$ and $\mathrm{D}$ ). On the other hand, the presence of $\beta_{3}$-adrenoceptor was tested with the specific $\beta_{3}$-adrenoceptor agonist BRL 37344. Figure 6 shows that the addition of isoprenaline, a general $\beta$ adrenoceptor agonist, stimulated cyclic AMP generation with $\mathrm{EC}_{50}$ seen at $120 \pm 15 \mathrm{nM}$. In contrast, BRL 37344 exhibited an
A

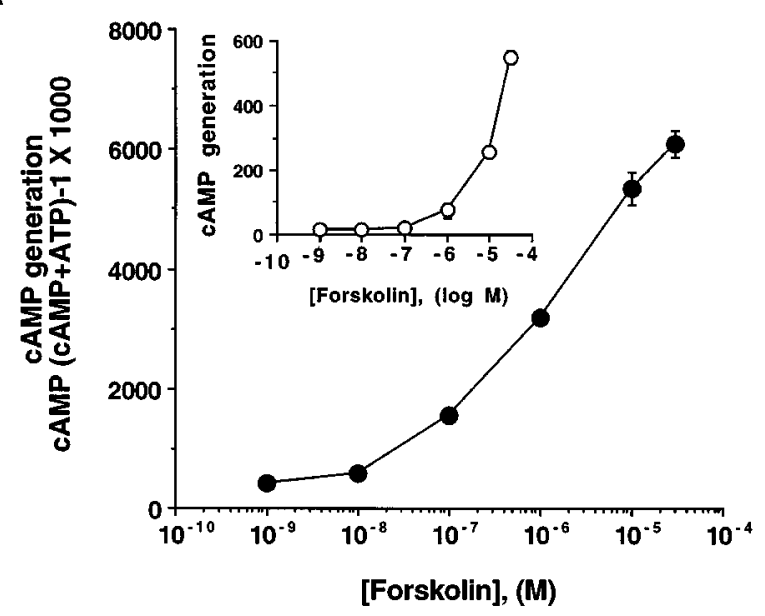

B

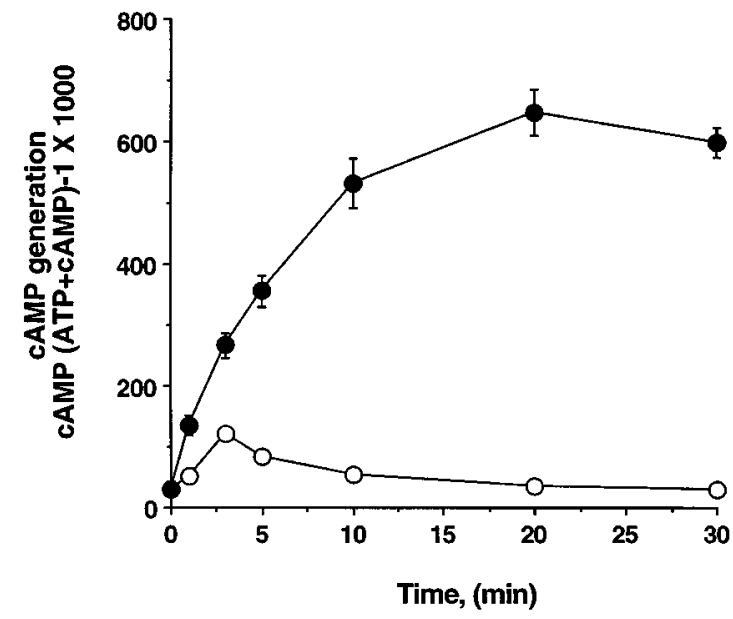

Figure 3 Enhancement of forskolin-stimulated cyclic AMP generation by adrenaline. (A) $\left[{ }^{3} \mathrm{H}\right]$ adenine-loaded PGT- $\beta$ cells were preincubated with IBMX $(1 \mathrm{mM})$ for $20 \mathrm{~min}$ and then stimulated with various concentrations of forskolin plus $1 \mu \mathrm{M}$ adrenaline $(\mathbf{)})$ for $20 \mathrm{~min}$. The inset shows the concentration-dependent changes in forskolin-stimulated $(O)$ cyclic AMP generation. (B) The timedependent changes in cyclic AMP accumulation induced by $10 \mu \mathrm{M}$ forskolin plus $1 \mu \mathrm{M}$ adrenaline $(\bigcirc)$ or forskolin alone $(\bigcirc)$ for the indicated times $(0,1,3,5,10,20,30 \mathrm{~min})$ in the absence of IBMX. The cyclic AMP levels were measured as described in Methods. The experiments were done three times and each point is the mean \pm s.e.mean.

$\mathrm{EC}_{50}$ of $184 \pm 28 \mu \mathrm{M}$, which is approximately $10^{3}$ fold higher concentration than that of isoprenaline. The data, therefore, indicate that the effects of adrenaline or noradrenaline on cyclic AMP generation occur primarily through the $\beta_{2^{-}}$ adrenoceptors on the cells.

\section{Elevation of the $N$-acetyltransferase activity upon $\beta_{2}$-adrenoceptor stimulation}

Because it has been known that $\beta$-adrenoceptor-induced cyclic AMP generation is responsible for $\mathrm{N}$-acetyltransferase gene expression in the pineal gland by involvement of the cyclic AMP response element (Baler et al., 1997), we measured the Nacetyltransferase activity after stimulating the adrenoceptors. Figure 7 shows that treatment with $1 \mu \mathrm{M}$ adrenaline and $10 \mu \mathrm{M}$ forskolin elevated the $\mathrm{N}$-acetyltransferase activity according to 
A

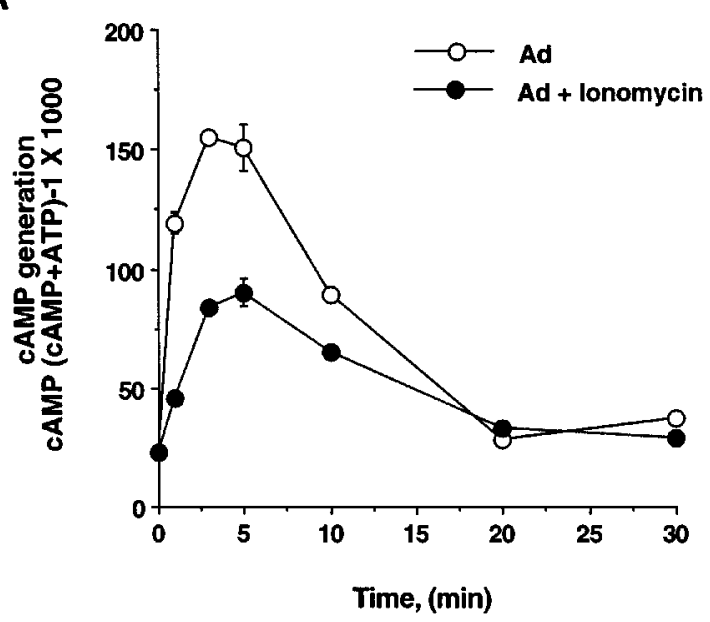

B

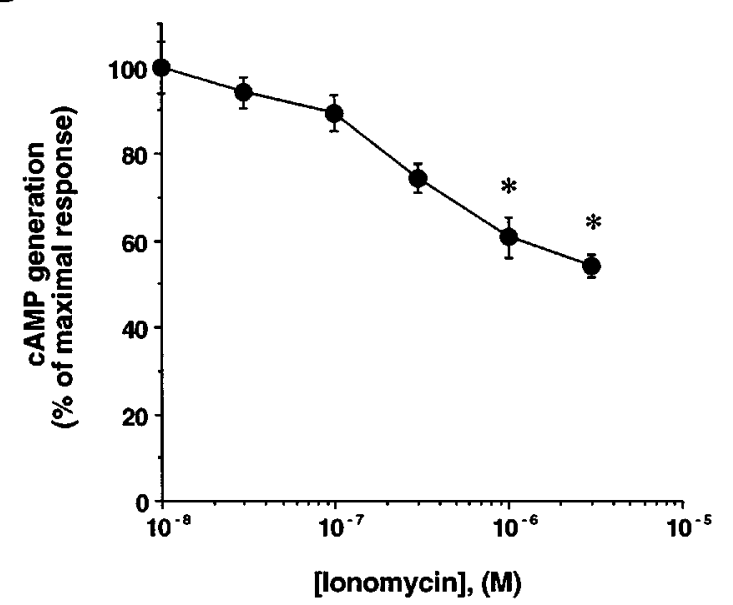

C

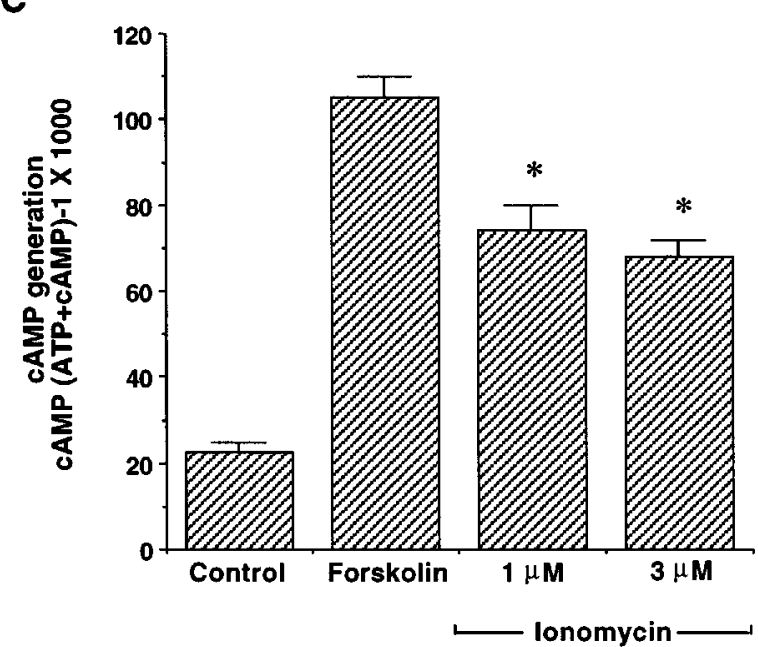

Figure 4 Effects of ionomycin on cyclic AMP generation. (A) Timedependent changes in intracellular cyclic AMP levels stimulated by $1 \mu \mathrm{M}$ adrenaline in the presence or absence of $1 \mu \mathrm{M}$ ionomycin. (B) Concentration-dependent inhibition of adrenaline-stimulated cyclic AMP generation by ionomycin. $\left[{ }^{3} \mathrm{H}\right]$ adenine-loaded cells were treated with $1 \mu \mathrm{M}$ adrenaline and variable concentrations of ionomycin for $3 \mathrm{~min}$. The cyclic AMP generation was presented as percentage of the maximal response induced by treatment with $1 \mu \mathrm{M}$ adrenaline. (C) Inhibition of forskolin-stimulated cyclic AMP generation by ionomycin. $\left[{ }^{3} \mathrm{H}\right]$ adenine-loaded cells were treated with $10 \mu \mathrm{M}$ forskolin and ionomycin for $3 \mathrm{~min}$. The cyclic AMP levels were measured as described in Methods. The experiments were done three times and the results were reproducible. Data are the mean$\mathrm{s} \pm$ s.e.mean. ${ }^{*} P<0.05$, compared to control. incubation time. The peak level of $\mathrm{N}$-acetyltransferase activity was achieved $6 \mathrm{~h}$ after agonist stimulation and was followed by a slow decrease to the basal level within $24 \mathrm{~h}$. However, simultaneous addition of ICI-118,551 blocked the increase of enzyme activity. The results imply that the $\beta_{2}$-adrenoceptormediated cyclic AMP production is involved in the regulation of induction of the $\mathrm{N}$-acetyltransferase gene expression.

\section{Discussion}

Adrenoceptors are found in nearly all peripheral tissues and on many neuronal populations within the central nervous system (Bond \& Clarke, 1988). They mediate the central and peripheral action of the primary sympathetic neurotransmitter noradrenaline, and the primary adrenal medullary hormone and central neurotransmitter adrenaline. The adrenoceptors have been divided into three major types, $\alpha_{1^{-}}, \alpha_{2^{-}}$and $\beta$ adrenoceptors receptors based on several lines of evidence: differences in affinity of selective drugs, second-messenger responses, and differences in the predicted amino acid sequences of the adrenergic receptor proteins. However, as new pharmacological tools and new techniques for studying drug-receptor interactions have become available, each adrenoceptor type has been subdivided into an increasing number of distinct subtypes (Bylund et al., 1994). Mammalian tissues contain three types of $\beta$-adrenoceptor, $\beta_{1}, \beta_{2}$, and $\beta_{3}$, based on their pharmacological properties (Emorine et al., 1994). The $\beta_{1}$-adrenoceptor is equally sensitive to noradrenaline and adrenaline, whereas the $\beta_{2}$-adrenoceptor has a higher affinity for adrenaline than for noradrenaline (Blin et al., 1993; Nantel et al., 1993). In contrast, the $\beta_{3}$-adrenoceptor has a higher affinity for noradrenaline (Strosberg \& Pietri-Rouxel, 1996). It has been suggested that the $\beta_{1}$ - and $\beta_{2}$-adrenoceptors mediate the effects of circulating catecholamines and that the $\beta_{3}$-adrenoceptor subtype plays a major role in regulating lipolysis and thermogenesis in adipose tissue (Zilberfarb et al., 1997) and sympathetic nerve stimulation in the large intestine (Luckensmeyer \& Keast, 1998).

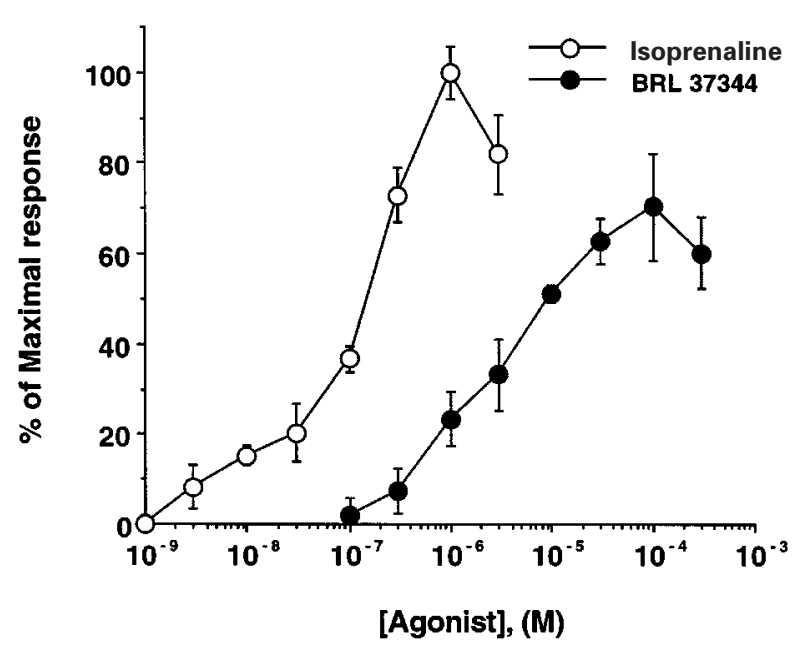

Figure 5 Effect of isoprenaline and BRL 37344 on cyclic AMP production in PGT- $\beta$ cells. $\left[{ }^{3} \mathrm{H}\right]$ adenine-loaded cells were preincubated with IBMX $(1 \mathrm{mM})$ for $20 \mathrm{~min}$ and then stimulated with variable concentrations of isoproterenol and BRL 37344 for $20 \mathrm{~min}$. The cyclic AMP generation was measured as described in Methods and presented as percentage of the maximal response induced by treatment with $1 \mu \mathrm{M}$ isoproterenol. The experiments were done three times and each point is the mean \pm s.e.mean. 
A
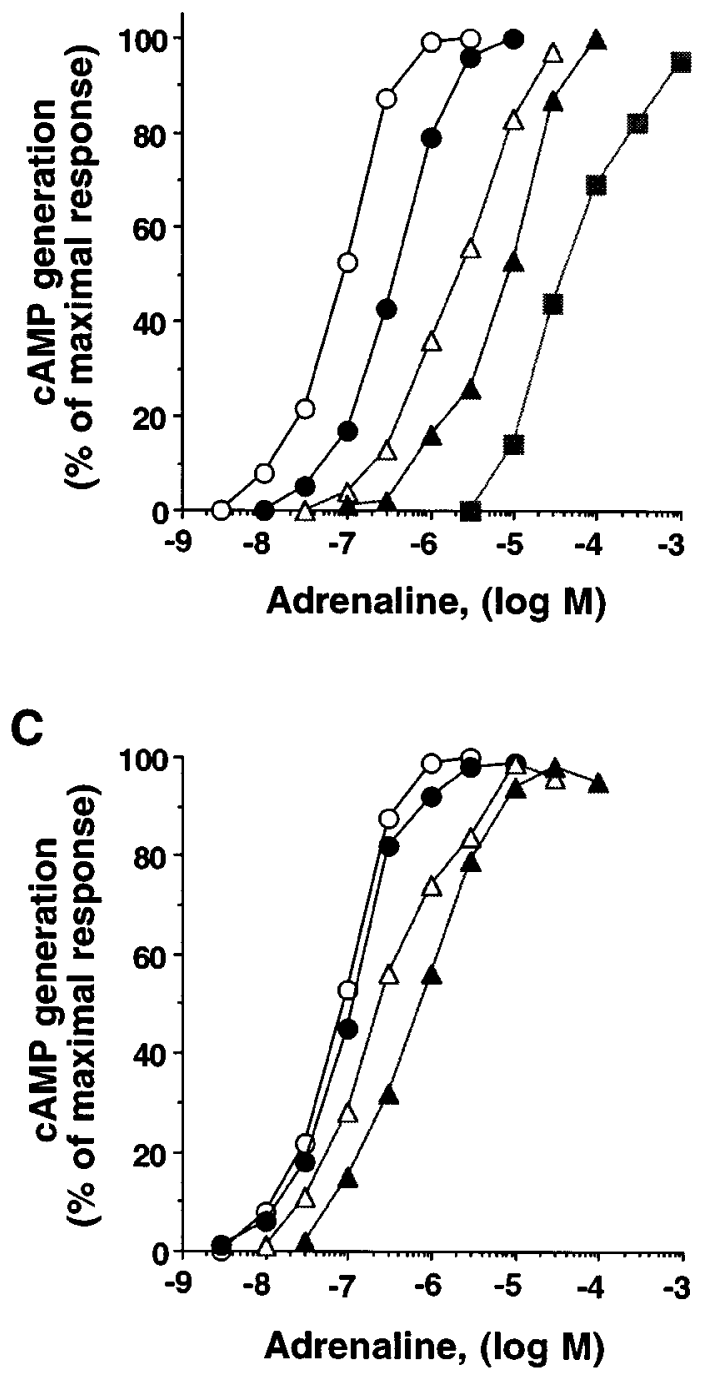

B

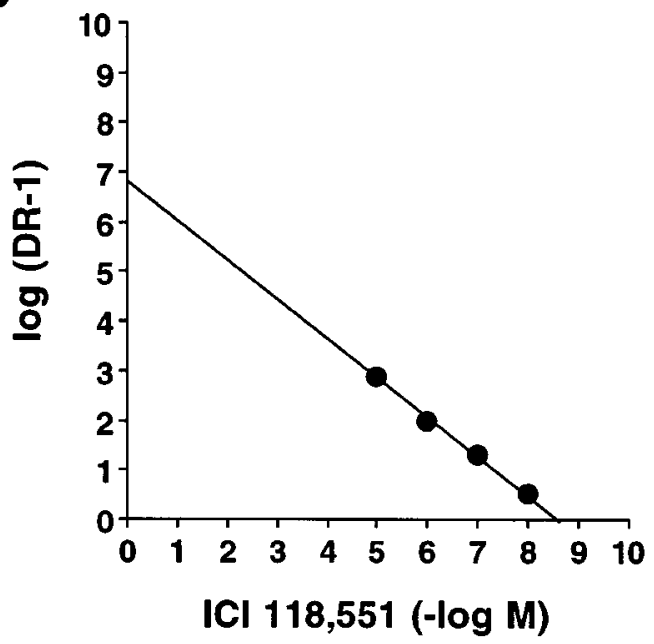

$\mathbf{D}$

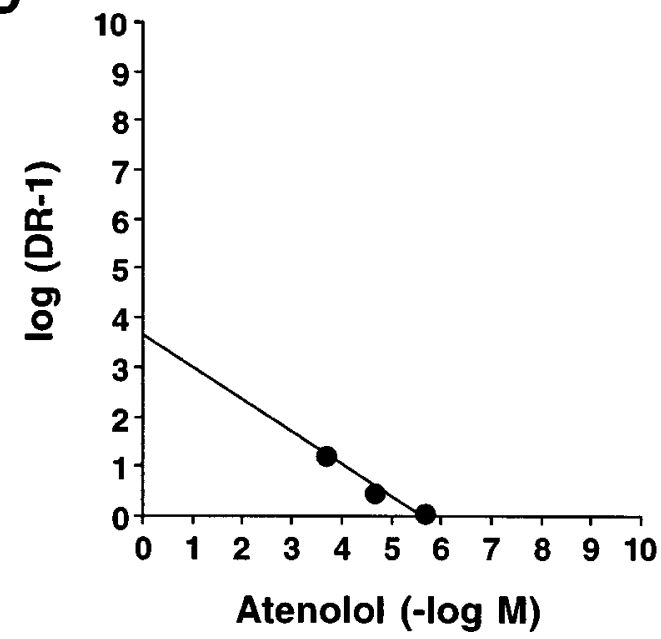

Figure 6 The antagonism by $\beta$-adrenoceptor antagonists of adrenaline-stimulated cyclic AMP generation. Concentration-response curves for the antagonistic effect of increasing concentrations of ICI 118,551 (A) and atenolol (C) on adrenaline-stimulated cyclic AMP generation are shown. The $\mathrm{pA}_{2}$ values of ICI 118,551 (B) and atenolol (D) were calculated for each antagonist by plotting: log $\left(\right.$ dose ration $\left.^{-1}\right)$ vs $-\log ($ antagonist) concentration. The concentrations of ICI 118,551 used to counteract the effects of adrenaline were $0(\bigcirc), 10 \mathrm{nM}(\mathbf{O}), 100 \mathrm{nM}(\Delta), 1 \mu \mathrm{M}(\mathbf{\Delta})$, and $10 \mu \mathrm{M}(\boldsymbol{\square})$. The concentrations of atenolol were $0(\bigcirc), 3 \mu \mathrm{M}(\mathbf{O}), 30 \mu \mathrm{M}(\Delta)$, and $300 \mu \mathrm{M}(\boldsymbol{\Delta})$. The concentration of adrenaline ranged from $10^{-9}-10^{-3} \mathrm{M}$. The cyclic AMP generation was presented as percentage of the maximal response induced by treatment with adrenaline. One typical experiment out of three independent experiments in duplicate is shown.

The present study clearly demonstrates the existence of $\beta_{2}$ adrenoceptors on the PGT- $\beta$ cell line which is established from the targeted pineal tumours in transgenic mice. In our experiments with subtype selective adrenergic receptor antagonists, the sensitivity to the inhibiting effect of the selective $\beta_{2}$-adrenoceptor antagonist ICI-118,551 was much more pronounced for the antagonistic effect of the selective $\beta_{1}$ adrenoceptor antagonist atenolol. The $\mathrm{pA}_{2}$ value for the ICI118,551 was $\sim 3$ units higher than that for atenolol. In addition, the $\beta_{3}$-adrenoceptor agonist BRL 37344 was 100 fold less potent in stimulating adenylyl cyclase than that of the general $\beta$-adrenoceptor agonist isoproterenol, which is consistent with the property of $\beta_{2}$-adrenoceptor (Dolan et al., 1994). Moreover, adrenaline was more effective in stimulating cyclic AMP generation than noradrenaline with a difference of $\sim 2$ orders of magnitude. Previous studies have shown that the distribution of adrenoceptor subtypes in mammalian pineal gland presents a species dependent difference. For example,
Machida et al. (1990) showed that the $\beta_{1}$-adrenoceptor is prominently distributed and functionally responsive to noradrenaline in the rat pineal gland. However, autoradiographic analysis in human post-mortem specimens demonstrate that $\beta_{2}$-adrenoceptors are present in an overlapping anatomical distribution with $\beta_{1}$-adrenoceptor throughout the gland (Little et al., 1996). Therefore, although the anatomical pattern of adrenergic receptor subtypes present on mouse pinealocytes was not elucidated, $\beta_{2}$-adrenoceptors might be primarily situated on mouse pineal gland. However, a possibility that the prominence of $\beta_{2}$-adrenoceptor in PGT- $\beta$ cells is due to the immature stage of the cells could not be excluded, since functional adrenergic stimulation required the developmental maturation of pinealocytes (Stehle et al., 1995). Duman et al. (1989) also reported that the mRNA levels of $\beta_{1}$ adrenoceptor is low on postnatal day 1 but increases several fold in parallel with an increase in $\beta_{1}$-adrenoceptor binding sites to adult levels, although the level of $G$ protein mRNA 


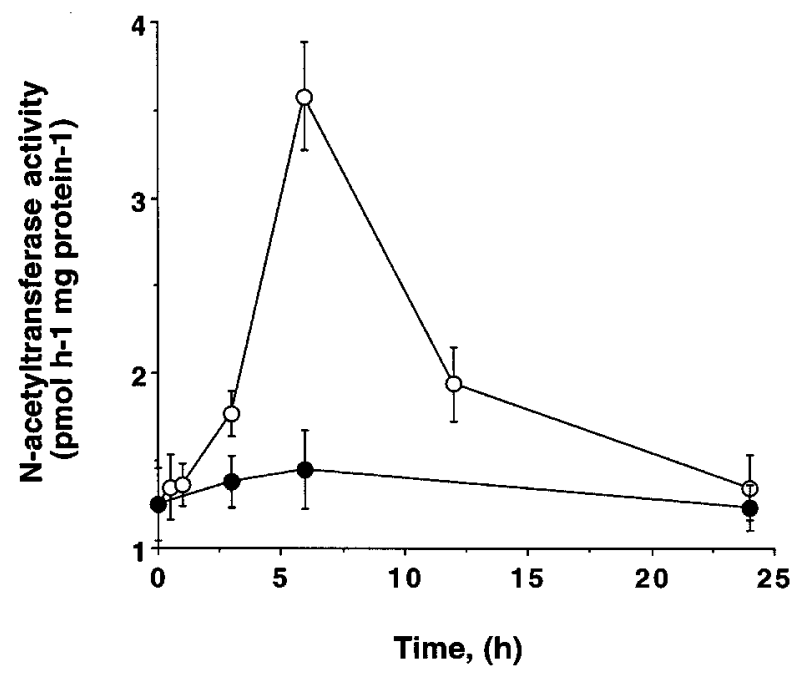

Figure 77 Time-dependent effect of $\beta$-adrenoceptor activation on $\mathrm{N}$ acetyltransferase activity in PGT- $\beta$ cells. The cells were treated with $1 \mu \mathrm{M}$ adrenaline and $10 \mu \mathrm{M}$ forskolin in the absence $(\bigcirc)$ or presence (0) of ICI-118,551 $(10 \mu \mathrm{M})$ for the indicated times $(0,1,3,6,12$, $24 \mathrm{~h}$ ) and $\mathrm{N}$-acetyltransferase activity was assayed as described in Methods. Results were confirmed by two independent experiments and expressed as the means \pm s.e.mean.

transcript on day 1 is equal to that of the adult. These reports, therefore, suggest that effective signalling of $\beta_{1}$-adrenoceptor in PGT- $\beta$ cells might require the developmental switch to $\beta_{1^{-}}$ adrenergic innervation on the differentiating processes of the cells.

Noradrenaline plays an important role in controlling pineal function through its effect on $\mathrm{N}$-acetyltransferase regulation in mammalian pineal glands (Roseboom \& Klein, 1995). Recently, in vitro studies with isolated rat pineal glands showed that noradrenaline elevated $\mathrm{N}$-acetyltransferase gene expression and enzyme activity more than 100 fold (Coon et al., 1995). The magnitude of the $\mathrm{N}$-acetyltransferase activity rhythm occurred over a $\sim 10$ fold difference in sheep (Namboodiri et al., 1985) and a $\sim 20$ fold difference in chicken (Binkley et al., 1973). However, in our PGT- $\beta$ cells, the Nacetyltransferase activity increased $\sim 3$ fold upon simultaneous stimulation with $1 \mu \mathrm{M}$ adrenaline and $10 \mu \mathrm{M}$ forskolin. This weak $\mathrm{N}$-acetyltransferase response may be due to the origin of the cells, since these pineal tumour PGT- $\beta$ cells were originated from transgenic mice which were hybrids of a circadian clockexpressing mouse $(\mathrm{CBA} / \mathrm{J})$ and a circadian clock-deficient mouse (C57BL/6J) (Son et al., 1996). Goto et al. (1989) demonstrates that most of the laboratory mice do not have pineal melatonin because of a genetic defect in the activity of $\mathrm{N}$-acetyltransferase. For example, C57BL/6J mice do not have $\mathrm{N}$-acetyltransferase activity because of a mutation in an autosomal gene required for the normal activity of $\mathrm{N}$ acetyltransferase (Goto et al., 1994). However, our experiment with PGT- $\beta$ cells shows that the noradrenaline's effect on cyclic AMP generation was only significant at above 100 micromolar concentrations. Accordingly, it seems likely that the coupling between noradrenaline released from superior cervical ganglion and adrenergic receptor could not function efficiently in the mouse pineal gland, which might be one of the causes for loss of pineal function in the circadian rhythm of the mouse.

Our finding that the elevation of $\mathrm{N}$-acetyltransferase activity occurred $6 \mathrm{~h}$ after agonists stimulation was consistent with previous studies in which the pineal $\mathrm{N}$-acetyltransferase activity peaked $6-9 \mathrm{~h}$ after adrenergic stimulation and then slowly declined to the basal level within 24 h (Roseboom \& Klein, 1995). The time interval between receptor stimulation and the subsequent elevation of $\mathrm{N}$-acetyltransferase activity indicates that the increase in $\mathrm{N}$-acetyltransferase activity was the result of gene expression and subsequent enzyme protein synthesis.

The present results are particularly significant insofar as they show that the distribution of adrenoceptors and the adrenoceptor-adenylyl cyclase system differ according to the species. They also support the conclusion that the $\beta$ adrenoceptors-mediated signals are responsible for the regulation of $\mathrm{N}$-acetyltransferase activity. The pharmacological results also clearly indicate that $\beta_{2}$-adrenoceptors are expressed and coupled to the adenylyl cyclase system in the mouse pineal gland.

We are grateful to S. Han for helping with the assay of cyclic AMP measurement. We also thank Ms G. Hoschek for editing the manuscript. This work was supported by grants from POSTECH/ BSRI Special fund, the Korea Science and Engineering Foundation (KOSEF 97-0401-02), the Basic Science Research Institute Program (Project BSRI-98-4435) from the Ministry of Education.

\section{References}

ARONSON, B.D., BELL-PEDERSEN, D., BLOCK, G.D., BOS, N.P., DUNLAP, J.C., ESKIN, A., GARCEAU, N.Y., GEUSZ, M.E., JOHNSON, K.A., KHALSA, S.B., HOFFEN, G.C.K., KOUMENIS, C., LEE, T.M., LESAUTER, J., LINDGREN, K.M., LIU, Q., LOROS, J.J., MICHEL, S.H., MIRMIRAN, M., MOORE, R.Y., RUBY, N.F., SILVER, R., TUREK, F.W., ZATZ, M., \& ZUCKER, I. (1993). Circadian rhythms. Brain Res. Rev., 18, 315-333.

BAlER, R., COVINGTON, S. \& KLEIN, D.C. (1997). The rat arylalkylamine $\mathrm{N}$-acetyltransferase gene promoter. cAMP activation via a cAMP-responsive element-CCAAT complex. J. Biol. Chem., 272, 6979-6985.

BINKLEY, S.A., MACBRIDE, S.E., KLEIN, D.C. \& RALPH, C.L. (1973). Pineal enzymes: regulation of avian melatonin synthesis. Science, 181, 273-275.

BLIN, N., CAMOIN, L., MAIGRET, B. \& STROSBERG, A.D. (1993). Structural and conformational features determining selective signal transduction in the $\beta_{3}$-adrenergic receptor. Mol. Pharmacol., 44, $1094-1104$

BOND, R.A \& CLARKE, D.E (1988). Agonist and antagonist characterization of a putative adrenoceptor with distinct pharmacological properties from the alpha- and beta-subtypes. Br. J. Pharmacol., 95, 723-734.

BREZEZINSKI, A. (1997). Melatonin in humans. N. Engl. J. Med., 336, $186-193$.

BROWNSTEIN, M., SAAVEDRA, J.M. \& AXELROD, J. (1973). Control of pineal $\mathrm{N}$-acetylserotonin by a $\beta$-adrenergic receptor. Mol. Pharmacol., 9, 605-611.

BYLUND, D.B., EIKENBERG, D.C., HIEBLE, J.P., LANGER, S.Z., LEFKOWITZ, R.J., MINNEMAN, K.P., MOLINOFF, P.B., RUFFOLO JR, R.R. \& TRENDELENBURG, U. (1994). International union of pharmacology nomenclature of adrenoceptors. Pharmacol. Rev., 46, $121-136$.

CHALLISS, R.A., CHILVERS, E.R., WILLCOCKS, A.L. \& NAHORSKI, S.R. (1990). Heterogeneity of $\left[{ }^{3} \mathrm{H}\right]$ inositol 1,4,5-trisphosphate binding sites in adrenal-cortical membranes. Biochem. J., 265, $421-427$. 
COON, S.L., ROSEBOOM, P.H., BALER, R., WELLER, J.L., NAMBOODIRI, M.A.A., KOONIN, E.V. \& KLEIN, D.C. (1995). Pineal serotonin N-acetyltransferase: expression cloning and molecular analysis. Science, 270, $1681-1683$.

DE LEAN, A., MUNSON, P.J. \& RODLAND, D. (1978). Simultaneous analysis of families of sigmoidal curves: application to bioassay, and physiological dose-curves. Am. J. Physiol., 235, E97-E102.

DOLAN, J.A., MUENKEL, H.A., BURNS, M.G., PELLEGRINO, S.M., FRASER, C.M., PIETRI, F., STROSBERG, A.D., LARGIS, E.E., DUTIA, M.D., BLOOM, J.D., BASS, A.S., TANIKELLA, T.K., COBUZZI, A., LAI, F.M. \& CLAUS, T.H. (1994). Beta-3 adrenoceptor selectivity of the dioxolane dicarboxylate phenethanolamines. J. Pharmacol. Exp. Ther., 269, 1000-1006.

DUMAN, R.S., SAITO, N. \& TALLMAN, J.F. (1989). Development of $\beta$-adrenergic receptor and $\mathrm{G}$ protein messenger RNA in rat brain. Mol. Brain Res., 5, 289-296.

EBADI, M. \& GOVITRAPONG, P. (1986). Neural pathways and neurotransmitters affecting melatonin synthesis. J. Neural Transm. Suppl., 21, 125-155.

EMORINE, L.J., BLIN, N. \& STROSBERG, A.D. (1994). The human $\beta_{3}$ adrenoceptor: the search for a physiological function. Trends Pharmacol. Sci., 15, 3-7.

GOTO, M., OSHIMA, I., HASEGAWA, M. \& EBIHARA, S. (1994). The locus controlling pineal serotonin $\mathrm{N}$-acetyltransferase activity (Nat-2) is located on mouse chromosome 11. Mol. Brain Res., 21, $349-354$.

GOTO, M., OSHIMA, I., TOMITA, T. \& EBIHARA, S. (1989). Melatonin content of the pineal gland in different mouse strains. J. Pineal Res., 7, $195-204$.

KLEIN, D.C \& MOORE, R.Y (1979). Pineal N-acetyltransferase and hydroxyindol- $O$-methyltransferase: control by the retinohypothalamic tract and the suprachiasmatic nucleus. Brain Res., 174, 245-262.

LITTLE, K.Y., KIRKMAN, J.A. \& DUNCAN, G.E. (1996). $\beta$-adrenergic receptor subtypes in human pineal gland. J. Pineal Res., 20, $15-$ 20.

LUCKENSMEYER, G.B. \& KEAST, J.R. (1998). Activation of $\alpha$ - and $\beta$ adrenoceptors by sympathetic nerve stimulation in the large intestine of the rat. J. Physiol., 510, 549-561.

MACHIDA, C.A., BUNZOW, J.R., SEARLES, R.P., TOL, H.V., TESTER, B., NEVE, K.A., TEAL, P., NIPPER, V. \& CIVELLI, O. (1990). Molecular cloning and expression of the $\beta_{1}$-adrenergic receptor gene. J. Biol. Chem., 265, $12960-12965$.

NAMBOODIRI, M.A.A., SUGDEN, D., KLEIN, D.C., GRADY, JR R. \& MEFFORD, I.N. (1985). Rapid nocturnal increase in ovine pineal $\mathrm{N}$-acetyltransferase activity and melatonin synthesis: effects of cycloheximide. J. Neurochem., 45, 832-835.
NANTEL, F., BONIN, H., EMORINE, L.J., ZILBERFARB, V., STROSBERG, A.D., BOUVIER, M. \& MARULLO, S. (1993). The human $\beta_{3}$ adrenergic receptor is resistant to short term agonist-promoted desensitization. Mol. Pharmacol., 43, 548-555.

ROSEBOOM, P.H., COON, S.L., BALER, R., MCCUNE, S.K., WELLER, J.L. \& KLEIN, D.C. (1996). Melatonin synthesis: analysis of the more than 150-fold nocturnal increase in serotonin $\mathrm{N}$-acetyltranferase messenger ribonucleic acid in the rat pineal gland. Endocrinology, 137, 3033-3044.

ROSEBOOM, P.H. \& KLEIN, D.C. (1995). Noradrenaline stimulation of pineal CREB phosphorylation: primary role of a $\beta$-adrenergic $\rightarrow$ cyclic AMP mechanism. Mol. Pharmacol., 47, 439-449.

SON, J.H., CHUNG, J.H., HUH, S.O., PARK, D.H., PENG, C., ROSENBLUM, M.G., CHUNG, Y.I. \& JOH, T.H. (1996). Immortalization of neuroendocrine pinealocytes from transgenic mice by targeted tumorigenesis using the tryptophan hydroxylase promoter. Mol. Brain. Res., 37, $32-40$.

STEHLE, J.H., FOULKES, N.S., PEVET, P. \& SASSONE-CORSI, P. (1995). Developmental maturation of pineal gland function: synchronized CREM inducibility and adrenergic stimulation. Mol. Endocrinol., 9, 706-716.

STROSBERG, A.D. \& PIETRI-ROUXEL, F. (1996). Function and regulation of the $\beta_{3}$-adrenoceptor. Trends Pharmacol. Sci., 17, $373-381$.

SUGDEN, D., VANECEK, J., KLEIN, D.C., THOMAS, T.P. \& ANDER SON, W.B. (1985). Activation of protein kinase C potentiates isoprenaline-induced cyclic AMP accumulation in rat pinealocytes. Nature, 314, 359-361.

SUH, B.C. \& KIM, K.T. (1995). Stimulation of adenylyl cyclase mediated by phospholipase $\mathrm{C}$-linked $\mathrm{M}_{3}$ muscarinic receptor in human neuroblastoma SK-N-BE(2)C cells. J. Neurochem., 64 $2500-2508$.

SUH, B.C., SON, J.H., JOH, T.H. \& KIM, K.T. (1997). Two distinct P $_{2-}$ purinergic receptors, $\mathrm{P}_{2 \mathrm{Y}}$ and $\mathrm{P}_{2 \mathrm{U}}$, are coupled to phospholipase $\mathrm{C}$ in mouse pineal gland tumor cells. J. Neurochem., 68, $1622-$ 1632.

TAKAHASHI, J.S. (1993). Circadian clocks a la CREM. Nature, $\mathbf{3 6 5}$ $299-300$.

YU, L., SCHAAD, N.C. \& KLEIN, D.C. (1993). Calcium potentiates cAMP stimulation of pineal arylalkylamine $\mathrm{N}$-acetyltransferase. J. Neurochem., 60, 1436-1443.

ZILBERFARB, V., PIETRI-ROUXEL, F., JOCKERS, R., KRIEF, S., DELOUIS, C., ISSAD, T. \& STROSBERG, A.D. (1997). Human immortalized brown adipocytes express functional $\beta_{3}$-adrenoceptor coupled to lipolysis. J. Cell Sci., 110, 801-807.

(Received May 22, 1998

Revised September 2, 1998 Accepted September 23, 1998 